\title{
Natural Resource Utilization and Problems in Haryana
}

\author{
Sheetal
}

M.A. Geography, IGU Meerpur, Rewari, Haryana, India

\begin{abstract}
There is a need for strengthening the Department of Agro-meteorology for mainstreaming the climate change related mitigation and adaptation measures into natural resource management research and development to begin with climate smart and weather forecast based agriculture in the State. Increased use of fossil fuel, puddled rice cultivation and large bovine cattle population in the country are major sources of emission of GHG and global warming. The research results suggest that the C3 crops will be benefited from CO2 enrichment, but the elevated temperature will increase water use, reduce maturity duration and productivity due to global warming.
\end{abstract}

Keywords : Natural Resource. Resource Management, agriculture, water management, soil conservation, Haryana, HAU Hisar

\section{INTRODUCTION}

Carved out as a separate State from the erstwhile State of Punjab on November1, 1966, Haryana has total geographical area of 4.42 million ha that accounts for $1.4 \%$ of the total geographical area of the country and less than 2.6\% of country's population (Yadav and Kumar, 2010). Agriculture being the primary livelihood base, nearly $85 \%$ of the area is under cultivation, $3.52 \%$ is under forestry while remaining area accounts for non-agricultural uses.

The Haryana State, located between $27^{\circ} 30^{\prime}$ and $30^{\circ} 35^{\prime}$ $\mathrm{N}$ latitude and $74^{\circ} 28^{\prime}$ and $77^{\circ} 36^{\prime} \mathrm{E}$ longitude is a part of the north western arid and semiarid plains with an average rainfall of $545 \mathrm{~mm}$ that ranges from $1200 \mathrm{~mm}$ in the extreme north-east to less than $300 \mathrm{~mm}$ in the arid west. The State is bounded by Siwalik hills in the north, river Yamuna in the east and Aravali hills in the south. More than $98 \%$ of the area of the State is covered by alluvial plains including the western deserted terrain of sand dunes. River Yamuna and
Ghaggar flood plains constitute a large part of the State and the entire area is covered by three basins (Fig.1): namely, Yamuna basin (16330 sq. km.), Ghaggar basin (10675 sq. km.) and Inland basin (17207 sq. km.). The altitude in the State varies from $190 \mathrm{~m}$ to $1200 \mathrm{~m}$ above msl whose consequential physiography is depicted in Fig.2. Topographically a large part of Haryana plains constitute a widely spaced topographic depression between Siwalik hills and Aravali hills which has created typical internal drainage condition in the central and western parts including the districts of Rohtak, Jhajjar, Bhiwani, Hisar, Sirsa and parts of Sonipat (Fig 1). Haryana has a unique geographical feature whose water travels both into Indus and Ganges basins.

Forested areas in Haryana State are declining due to harsh conditions, overgrazing, the expansion of farmland and rapid urbanization. The objective of the Integrated Natural Resource Management and Poverty Reduction Project (INRMPRP) in Haryana is to regenerate the forest through forest resource 
management activities such as afforestation, watershed protection and soil conservation. This will result in long-term development of nature and society in the region as the standard of living improves for the people who live in and around the forest. Through the INRMPRP in Haryana, community participation afforestation activities are being carried out on land totaling approximately 50 thousand hectares. Additionally, the project aims to reduce poverty by carrying out small-scale infrastructure improvements in villages and provide job training to help residents dependent on the forests for their livelihoods find alternative sources of income. Furthermore, in order to dynamically develop the organizational skills of the Forest Department and the community, various teaching and awareness activities and training are being carried out. In this way, efforts are being made not only for facilitating afforestation activities, but also activities that aim to ensure sustainability for the regenerated forests. As a sub-component of the INRMPRP in Haryana, the Children's Forest Program is being implemented in coordination with a Japanese non-governmental organization, the Organization for Industrial, Spiritual and Cultural Advancement (OISCA).

The State has made great strides in food production and contributes significantly to the national food basket. The Green Revolution has helped to bring around $85 \%$ of the total geographical area under cultivation with a cropping intensity of about $181 \%$. However, recent agricultural trends in agriculture production are not very encouraging. The indiscriminate use of natural resources in intensively cultivated areas of Haryana has started showing negative impacts on soil health, progressive decline in input use efficiency and total factor productivity and increase in cost of cultivation, pollution of water and environment and threat of climate change on agriculture, and thus a real challenge to sustain $4 \%$ or higher growth of agriculture sector in the State. Inevitably, the food security situation is likely to become critical in the changing scenario if urgent actions to prepare the farmers to adopt appropriate soil, water and crop management practices to face the futuristic problems of resource constraints are not taken.

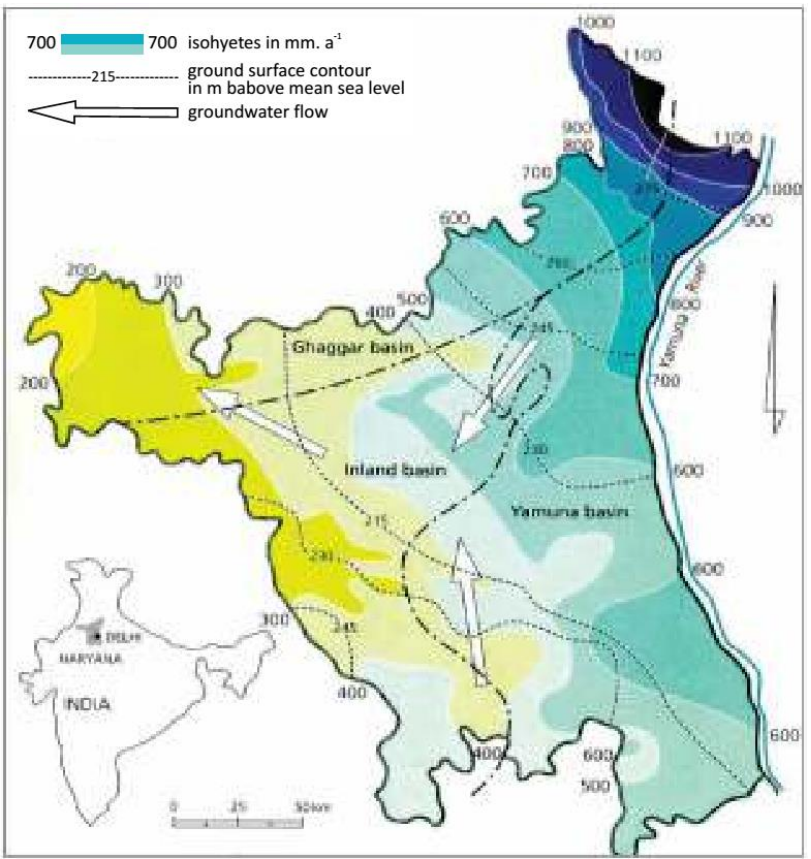

Fig. 1: Geographic domain of Haryana

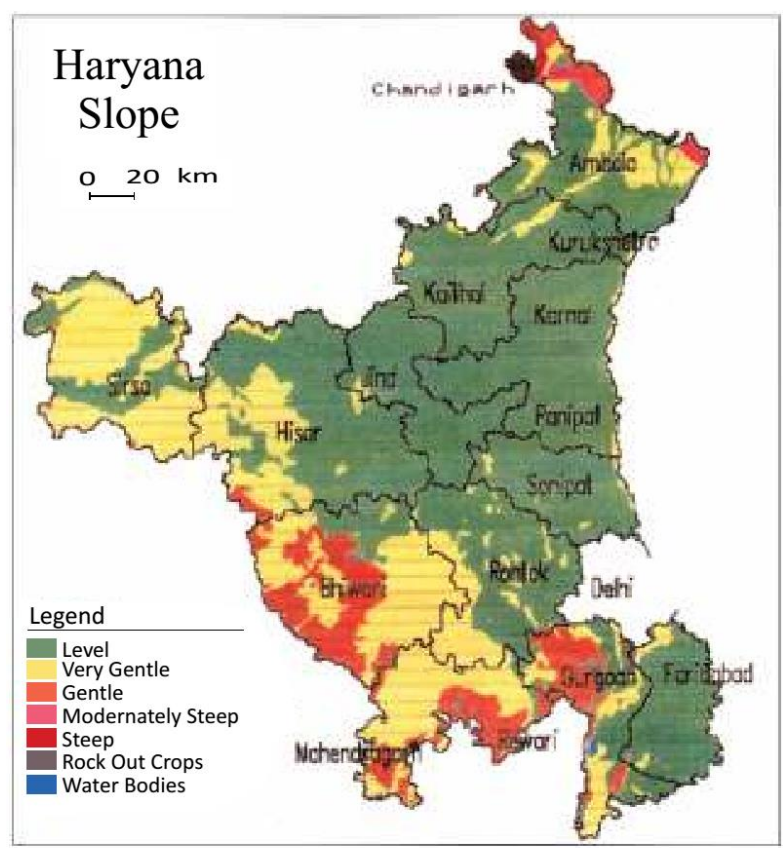

Fig.2: Haryana physiography 


\subsection{NATURAL RESOURCES}

\subsubsection{Soil Resources}

Soil resources of the State are developed on alluvium in the plains and on detrital and alluvial materials in northern sub-mountains tracks, an aeolian material in the extreme western fringe and on alluvium modified by aeolian activity in southern and south western part of the State. Taxonomically, Inceptisols are dominant soils occupying about $58 \%$ of the area followed by Entisols (28\%), Aridisols (9\%) and Alfisols (2\%) (Fig.3). Texturally, fine loamy soils are dominant and cover $43 \%$ of the area, coarse loamy soils cover $34 \%$ and sandy soils $23 \%$ of the total area.
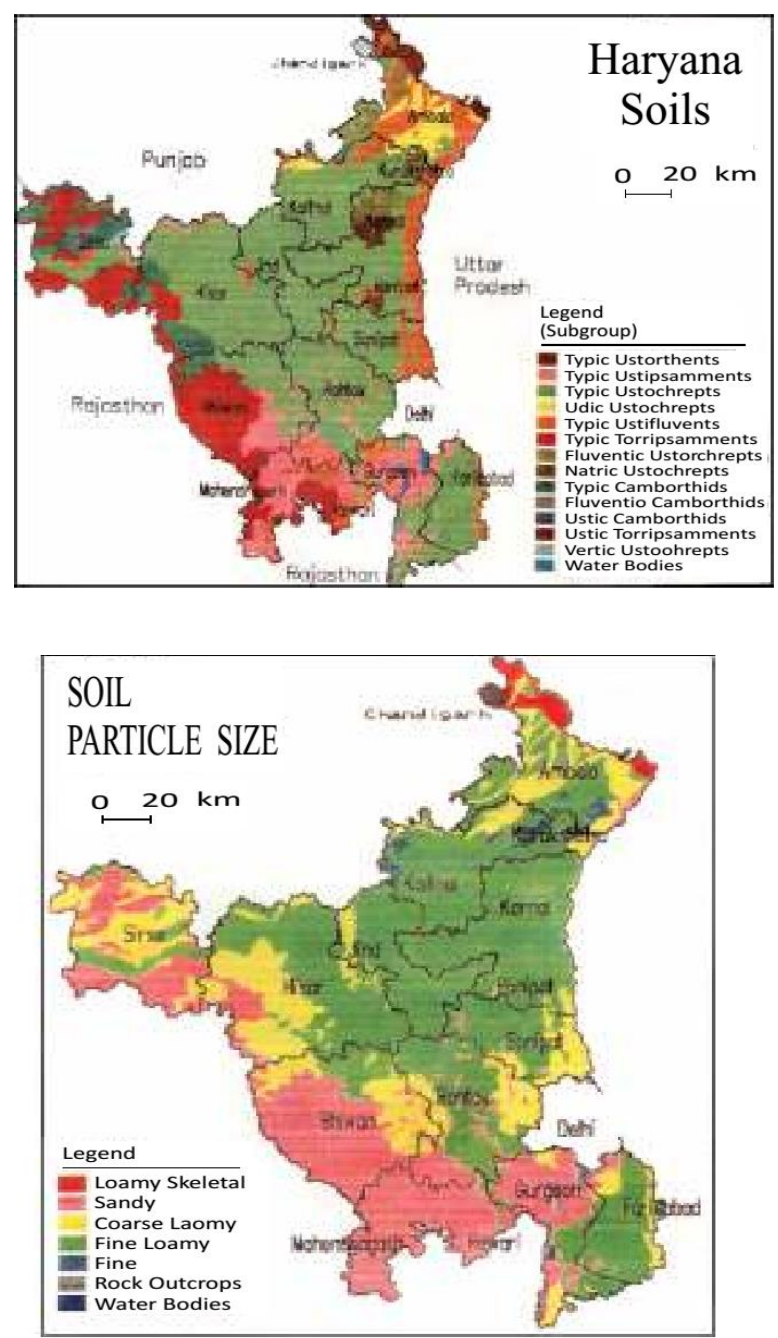

Fig. 3: Soil resources of Haryana (Textural classification

\subsubsection{Water Resources}

The total potential of surface and ground water resource is estimated at 1.51 and $1.24 \mathrm{~m}$ ha $\mathrm{m}$ respectively, amounting to $2.75 \mathrm{~m}$ ha $\mathrm{m}$ including ground water of marginal quality (Figs. 5, 6). The north eastern part of the State is extensively underlain by fresh ground water, the remaining $28,000 \mathrm{~km}^{2}$ (about $60 \%$ ) is underlain by brackish to very saline groundwater. Considering urban and industrial needs of water resources, existing available water resources can meet hardly $60 \%$ of the irrigation requirements. Over the past 4 to 5 decades, all out efforts have been made to tap all available resources to meet agricultural needs. Western Yamuna Canal originating from river Yamuna, and Bhakra Canal originating from river Sutlej constitute the main surface irrigation system. The Western Yamuna Canal which takes water up to Hisar is one of the oldest canals of this region, constructed in 1351AD by Ferozshah Tuglak and remodeled later by King Shahjahan. Secondary and tertiary canal systems include Gurgaon and a number of lift irrigation projects including Jui, Indira Gandhi, B. N. Chakraborty and Jawaharlal Nehru lift irrigation schemes that raise water in stages upto $174 \mathrm{~m}$ to bring irrigation to sandy tracks of western and southern Haryana (For other details, see Fig.7).

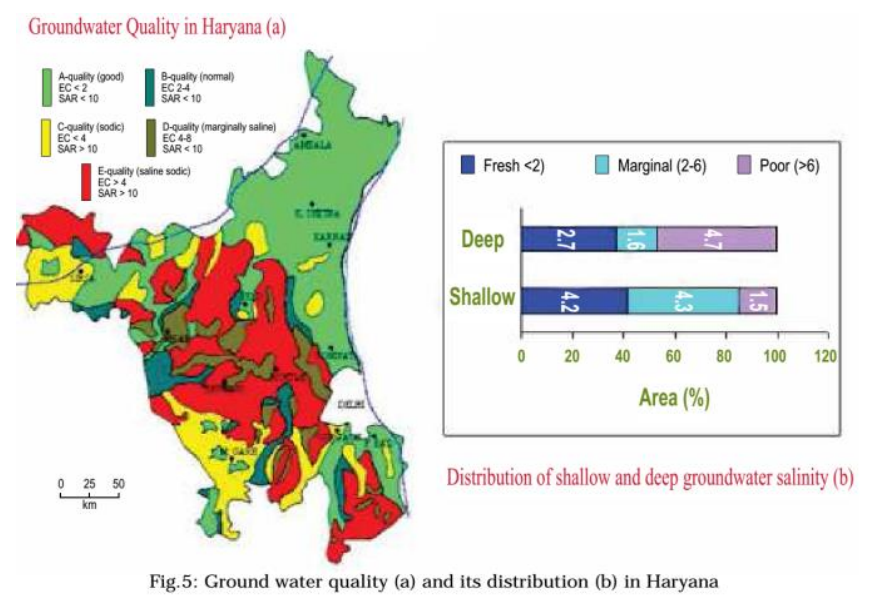




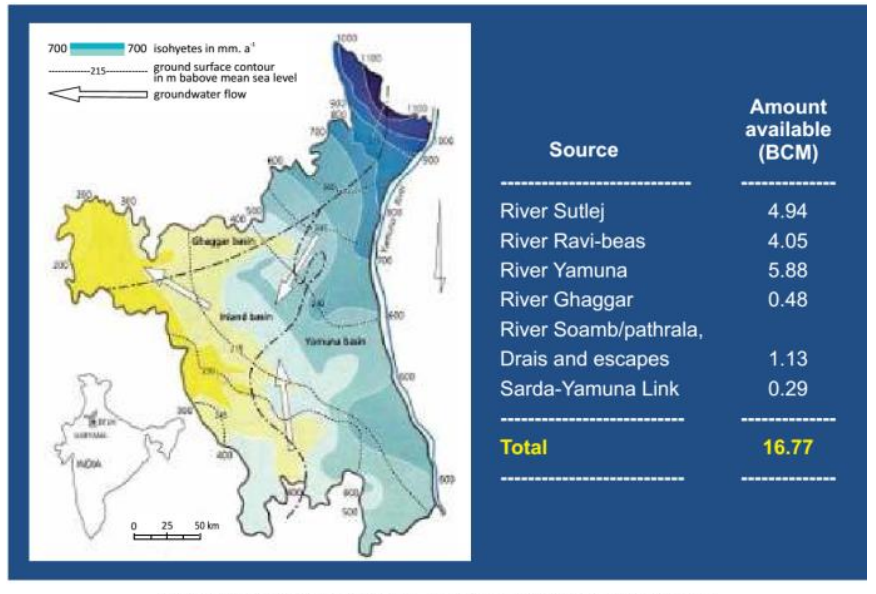

Fig.6: Source and amount of available surface water in Haryana

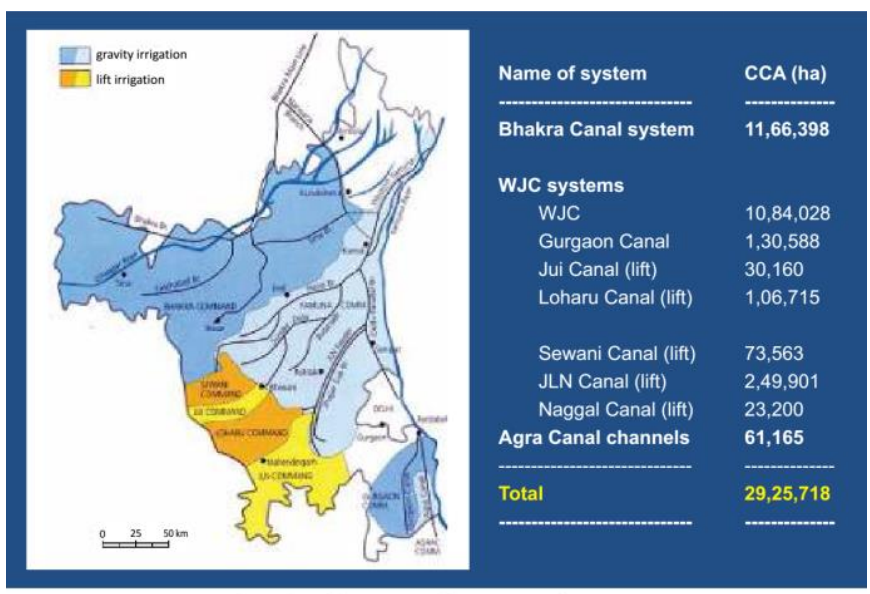

Fig.7: Surface (canal) water supply system and its CCA in Haryana

\subsubsection{Climate and Agroecological Zones}

The climate of the region being semi arid and arid, water resources of the State have played a critical role in the improvement and sustainability of agricultural production. Mean annual rainfall of $545 \mathrm{~mm}$, is received unevenly in the State (Fig. 8) and the annual evaporation demand exceeds $1500 \mathrm{~mm}$. The GCM models predicted that the Indian Sub-continental will be warmer by about $1.5^{\circ} \mathrm{C}$ during the middle of current century, and the second half of the winter will be warmer than the first half. It is also predicted that the Indian sub-continent would receive about $6 \%$ more rains which could be irregular and more intense. There will be some reduction in the incident radiation and increase in the concentration of $\mathrm{CO} 2$ and other green house gases during the current century. Thus, there is a need to undertake appropriate adaptation and mitigation measures to address the impact of climate change on agriculture.

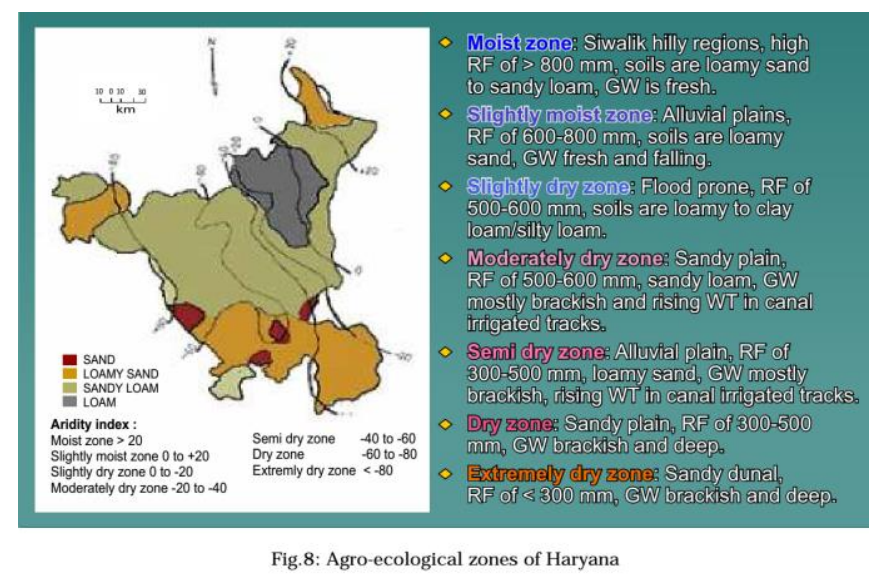

1.2.4 Crops, Cropping Systems and Biodiversity

Agro-climatic resource conditions, development of water resources and the State policies have contributed to the prevalent crops and farming systems in different parts of the State. The main aim of research and development was to maximize the productivity of crops with relatively little attention to sustainability of resource use and management. The crop cultivars currently grown are mostly modern short statured high yielding and have replaced many of the traditional cultivars adopted earlier by the farmers. With practically little attention devoted to understanding and addressing issue of biodiversity and its dynamics, it has started reflecting in emergence of new disease and pest scenario seriously threatening production base. As an example, introduction of high yielding varieties of rice and wheat crops and improvement in irrigation facilities and use of chemical fertilizers, the indigenous sorghum, maize and millets growing area has been shifted to mainly rice-wheat system. The traditional indigenous crops, their varieties/ races/ biotypes occurring naturally, which were not high yielding otherwise, had many desirable characters like resistance to various biotic and abiotic stresses and better quality. 


\subsubsection{Agricultural Development and State of Natural}

\section{Resources}

Over the past four decades, the State has made rapid strides to achieve goals of enhanced agricultural productivity and contributed significantly to achieve food grains production goals towards meeting the growing demand for increasing population, export etc. Expansion of area under irrigation involving a network of canals, minors, lift canals, support for sinking tubewells, credit and marketing constituted the core of the strategy to achieve production goals together with availability and adoption of improved high yielding crop cultivars, increased use of fertilizers and plant protection chemicals (Table1). These efforts driven by the Central Government and supported and implemented by the State Government in the form of number of 'schemes' have yielded dividends by way of Haryana emerging as a front runner State in agriculture.

\begin{tabular}{lcc}
\multicolumn{2}{l}{ Table 1: Agriculture Development in Haryana } & \\
\hline Area (000 ha) & $1966-67$ & $2010-11$ \\
Geographic Area & 4421 & 4421 \\
Cultivable area (\% of total geographic area) & 86.45 & 86.27 \\
Net sown area & 3423 & 3576 \\
Total cropped area & 4599 & 6484 \\
Cropping intensity (\%) & 134.4 & 181.3 \\
Net irrigated area & & \\
(i) Canals & 991 & 1277 \\
(ii) Minor irrigation & 302 & 1602 \\
Total & 1293 & 2879 \\
Gross irrigated area & 1736 & 5528 \\
\% Net irrigated area & 37.8 & 84.16 \\
\% Gross irrigated area & 37.7 & 86.00 \\
\hline
\end{tabular}

Source: website of Agriculture Department, Haryana

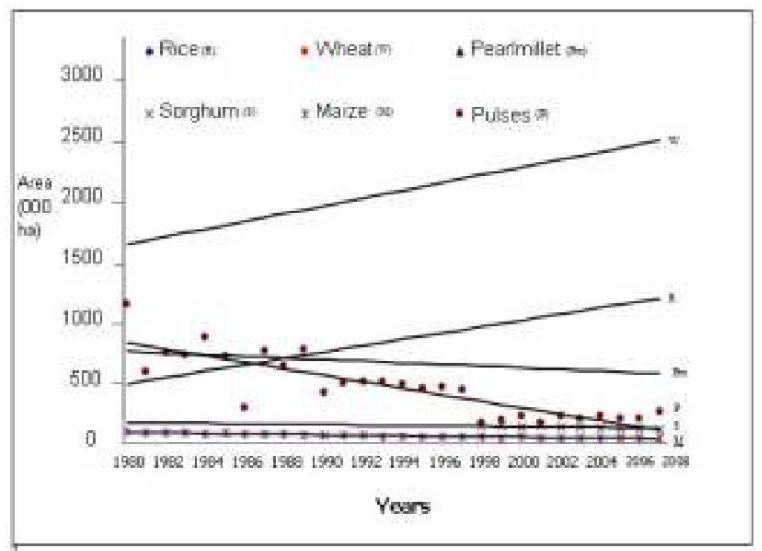

Fig. 9: Trends in acreage under food grain crops from 1981 to 2008

\subsection{POLICY ISSUES}

In order to find solution of location specific complex and interlinked problems of Natural Resource Management (Land, soil, water, biodiversity, climate) for sustainability of agriculture in the State, the Working Group observed that there is an urgent need to undertake the following activities/actions:-

- Seting up a school of Natural Resource Management and Environmental Sciences at CCS HAU, Hisar to prioritize, undertake and guide education, research and development for sustainable resource management in the State.

- The school should have multidisciplinary team of scientists drawn from the bio-physical, social and environmental sciences with expertise in areas of remote sensing-GIS applications and modeling of different components of natural resource system inclusive of soil resource, irrigation and drainage systems, watershed management, cropping and farming system, agroecology and climatic resources as well as resource use optimization.

- Encouraging use of organic manure, bio-fertilizer, green manure/ legumes in crop sequences, commissioning of bio-gas plants/ plantation of multipurpose trees to save cow dung from burning, promoting CA based technologies for recycling of crop residues and organic farming to improve organic carbon content in soils.

- Undertaking time bound programme to bring at least $50 \%$ area in next 10 years under pressurized system of irrigation and other water saving devices.

- Policy initiatives to shift the irrigation charges from irrigated area to volumetric basis to speed up the adoption of pressurized system of irrigation and other water saving devices to cover more area under irrigation by farmers in the canal commands. 
- Enforcement of laws banning diversion of untreated sewage water and industrial effluent in fresh water streams.

- Need of policy initiatives for increased allocation of canal water or adequate diversion of excess rainwater to water deficit arid regions but it should precede after scientific studies on salt and water balance, energy cost and socio-economic benefits on long run to the stakeholders.

- Promotion of managed forestry and agro-forestry by treating tree as crop for planting and harvesting purposes and incentive to farmers for undertaking agro-forestry, pisciculture and biodrainage under problematic soils and water conditions.

- Need for effective steps to focus on the large amount of biodiversity, both underground and above ground, for proper preservation and utilization in the State.

- Developing viable units for on-hand training in farming systems perspective with emphasis on intensification, diversification, resource conservation and value addition at the HQ of CCSHAU to train students, farmers and other stakeholders to develop entrepreneurship skills for employment/self employment, profitability and livelihood security of small farm holders.

- Need for establishing better coordination and accountability among different institutions, relevant State Government Departments, Central and other developmental agencies and stakeholders to find solutions of complex and interlinked problems of natural resource management to sustain growth of agriculture in the State.

\subsection{STATE OF NATURAL RESOURCES}

- Developing digital data base on status and dynamics of land use, soil, water, climate, vegetative cover and cropping and farming systems by HARSAC and SAU.

- Undertaking regular mapping and characterization of natural resources in digital form (Land, soil, water, climate, vegetative cover) and natural calamities (Drought, flood etc) using modern tools of remote sensing/GIS by HARSAC.

- Undertaking specific land use-cover change studies in relation to resource status/ degradation or other socioeconomic and development issues with a view to understand the nature of the driving forces and option to address the problems.

- Some of the issues which relate critically to sustained agricultural development include; declining farm size and area under prime agricultural lands, contamination of agricultural lands and groundwater systems by industrial and sewage waters, stagnating area under forestry cover and degradation of fragile erosion prone Aravallis and Shivalics.

- Bringing out 'The State of Natural Resources' report in digital form, every five years. The first report should be planned within the next two years. The initiative for this must come from CCSHAU and HARSAC.

\subsection{STRATEGIC, APPLIED AND ADAPTIVE RESEARCH}

- Need for greatly strengthened Regional Research Stations of CCS HAU to prioritize location specific research and development agenda in general and striving for better scientist-farmer connect- adaptive research projects in farmers participatory mode in particular to address regional specific issues of NRM in the State.

- Mainstreaming climate change related mitigation and adaptation measures through 
multidisciplinary strategic and adaptive research for development.

- Developing solutions to hydrological imbalances through integrated approaches involving on-farm water management, conjunctive use of water, pressurized system of irrigation and other water saving devices, surface and subsurface drainage, recharge of aquifers, diversification, intensification, CA based technologies and holistic watershed management approach.

- Amelioration of poor quality groundwater in inland basin through cyclic process of groundwater extraction and recharge with good quality water on pilot scale in farmer participatory mode.

- Developing full scientific package for use of waste water in peri-urban areas of the State, particularly for cultivation of vegetables and fodder crops.

- Undertaking holistic evaluation of selected executed projects in the areas of agricultural drainage, irrigation and watershed management and agroforestry with a view to assess their effectiveness in achieving the targeted objectives

- Making concerted efforts to substitute puddled rice with alternate crops such as hybrid maize/soybean based cropping systems and adoption of CA based technologies.

- Location specific concerted efforts for fine tuning of different resource conservation technologies (DSR, diversification, intensification, raised bed planting, residue incorporation, brown manuring etc) under different production systems.

- Developing alternate technologies for crop residue management in ricewheat and cottonwheat cropping system and use of biochar from crop residue to enhance $\mathrm{C}$-sequestration.

- Mainstreaming farming system research aimed at better understanding of farming system perspectives involving farmers, available resources and economic conditions and the way they interact with natural resources.

- Linking multi-enterprize models of integrated farming system with market, value addition, processing, handling and storage facilities of agriculture produce at production sites for livelihood security of small land holders.

\subsection{DEVELOPMENTAL ISSUES:}

- The clear focus of development efforts should be to help the farmers to manage their own resources in sustainable manner. - Development of scientific land use planning of the State using modern tools of remote sensing/GIS by HARSAC and CCSHAU, Hisar.

- Promoting integrated agricultural practices and strategies which improve organic carbon content of soils.

- Undertaking special drive for inclusion of legume or green manure crops in cereal-cereal cropping system either as catch or inter/mixed crops.

- Modifying existing soil health cards into system of "Soil Nutrient Management" by Department of Agriculture with greater emphasis to maintain soil organic matter and good soil health.

- Discouraging flood irrigation and encouraging pressurized system of irrigation and other water saving devices (Furrow irrigation, raised and sunken beds, fertigation, protected cultivation, plasticulture etc) through proper incentives to farmers.

- Augmentation of water supplies by conserving rainwater in the fields, aquifers, water bodies, conjunctive use of brackish and fresh waters, treatment of sewage and industrial effluent for use in irrigation and desilting of existing water bodies and construction of new water storage structures to cope up with scarcity of irrigation water. 
- Strengthening the capacity of the CCS Haryana Agricultural University, State Department of Agriculture and Irrigation Department to undertake training programmes to focus on improved on-farm water management using modern tools to extension workers, farmers and other stakeholders.

- Exploring all avenues to strengthen human resources base, both in terms of number and quality, through partnership with overseas institutes of repute in the field of Natural Resource Management in CCS Haryana Agricultural University, Hisar.

\section{REFERENCES}

[1]. Abrol, I. P., Gupta, R. and Malik, R. K. 2005. (Eds.). Conservation Agriculture-Status and prospects, CASA, New Delhi, 154p.

[2]. Antil, R. S. 2012. Integrated Nutrient Management for Sustainable Soil Health and Crop Productivity. Presentation in Productivity Enhancement Workshop conducted by Haryana Kisan Ayog, CCSHAU Campus, Hisar (Haryana).

[3]. Agarwal, M.C., Roest, C.W.J. 1996. Towards improved Water Management in Haryana State; Final Report of the Indo-Dutch Operational Research Project On Hydrological Studies. CCS Haryana Agricultural University, Hisar, International Institute for Land Reclamation and Improvement, Wageningen, DLO Winand Staring Centre for Integrated Land, Soil and Water Research, now Alterra Green World Research, Wageningen. P 80.

[4]. Anonymous , 1998. Management of water logging and salinity problems in Haryana. Master Plan. Govt. of Haryana.

[5]. Anonymous, 1991. Waterlogging, Salinity and Alkanity. Government of India, Ministry of Water Resources, New Delhi.
[6]. Bhattacharya, A. K. and Michael, A. M. 2003. Land Drainage: Principles, Methods and Applications. Konark Publishers Pvt Ltd, A-149, Main Vikash Marg, Delhi 110092.

[7]. Central Soil Salinity Research Institute, Karnal Annual Reports, 2005-06 to 2010-12.

[8]. Deora, A. 2012. Utilization of the strength and capacity of microbes in reclamation of problematic waters for irrigation. Abstract in International Seminar on Renewable Energy for Institutes and Communities in Urban and Rural Setting. Organized by Manav Institute of Technology, Hisar from April 27- 29, 2012.pp 15-16.

[9]. Dhindwal, A. S. and Jhorar, R. K. 2012. Water Resource Management in Haryana. Presentation in Productivity Enhancement Workshop conducted by Haryana Kisan Ayog, CCSHAU Campus, Hisar (Haryana).

\section{Cite this article as :}

Sheetal, "Natural Resource Utilization and Problems in Haryana", International Journal of Scientific Research in Science and Technology (IJSRST), Online ISSN : 2395-602X, Print ISSN : 2395-6011, Volume 6 Issue 5, pp. 43-50, September-October 2019. Journal URL : http://ijsrst.com/IJSRST19657 